\title{
Chemical Composition and Quality Attributes of Meat from West African Dwarf Goats Fed some Browse Species Supplemented with a Concentrate Diet
}

Ocheja, J.O ${ }^{1}$, Yahaya, $\mathrm{B}^{1}$, Bukola, O.A. ${ }^{1}$, Egbunu, $\mathrm{G}, \mathrm{F}^{2}$, Amidu, $\mathrm{M}^{2}$ and Effienokwu, J.N ${ }^{3}$

${ }^{1}$ Department of Animal Science, Federal University Kashere, Nigeria

${ }^{2}$ Department of Food, Nutrition and Home Science, Kogi State, University Anyigba, Nigeria

${ }^{3}$ Department of Science Laboratory Technology, Delta State Polytechnic, Ogwashi-Uku, Nigeria

DOI: $10.36347 /$ sjavs.2021.v08i05.002

| Received: 11.12 .2020 | Accepted: 21.12.2020 | Published: 30.05 .2021

*Corresponding author: Ocheja, J. O

\section{Abstract}

Original Research Article

Twenty (20) yearling west African dwarf goats were used in a study to determine the effects of some browse plants and a supplement diet on the chemical composition and some quality attributes of meat obtained from the goats The experiment lasted for 63 days after an adjustment period of 7 days, the goats were served water ad Libitum. Gmelina (T1), Tamarind (T2), Neem (T3) and Teak (T4) after wilting for 24 hours were fed at $300 \mathrm{~g} / \mathrm{goat} /$ day 2 hours before the concentrate. The supplement was fed at $100 \mathrm{~g} / \mathrm{goat} / \mathrm{day}$. At the end of the feeding trial three (3) goats from each treatment were slaughtered, bled, eviscerated and dressed and there after $60 \mathrm{~g}$ of meat were cut from the thigh of each of the slaughtered goats and used for the determination of their chemical composition and quality attributes. The experimental design was a completely randomized design, significant means were separated using SPSS version 23.0, 2015 edition, samples of the meat, concentrate diet and the browse plants were analyzed for their proximate composition using the methods outlined by AOAC $(2000)$. There were no significant $(\mathrm{P}<0.05)$ differences in the values for daily concentrate intake, ash, moisture, $\mathrm{pHi}$ and $\mathrm{pHu}$. Total daily feed intake ranged from $252.50-386.00 \mathrm{~g}$, and were significantly $(\mathrm{P}<0.05)$ different. Fat content values ranged from $4.45-10.05 \%$, and were significantly $(\mathrm{P}>0.05)$ different protein content values had a range of $18.40-23.15 \%$ and showed significant $(\mathrm{P}<0.05)$ differences values for drip loss, cooking losses, initial and ultimate $\mathrm{pH}$ were all significantly $(\mathrm{P}>0.05)$ different. The drip loss values ranged from $5.20-8.20 \%$, while the cooking loss values were $18.00-23.75 \%$, values for both parameters were significantly $(\mathrm{P}<0.05)$ different It was concluded that Gmelina (T1) produced goat meat with the best nutrients and quality parameters. Gmelina (T1) at 300g/goat /day as well as bambara nut waste and cereal spent grains based supplement diet were therefore recommended for feeding yearling West African dwarf goats for improved meat quality.

Keywords: Concentrate, Browse, Diets, Quality, Meat, West African Dwarf Goats.

Copyright $\left({ }_{0} 2021\right.$ The Author(s): This is an open-access article distributed under the terms of the Creative Commons Attribution 4.0 International License (CC BY-NC 4.0) which permits unrestricted use, distribution, and reproduction in any medium for non-commercial use provided the original author and source are credited.

\section{INTRODUCTION}

Goat meat (Chevon) serve as a major source of meat in developing countries, while it is less popular in western countries, nevertheless the perception about goat meat is changing due to the health benefits of the consumption of lean meat with reduced fat and cholesterol content [1]. Carcass fat content is generally low in goat meat, fat accretion occurs much less in the growth process compared with other species of ruminants. Goats have much less sub-cuteanous and intramuscular fat than sheep, they however have more fat in the abdomen, whilst sheep typically have about 30 percent of their body as fat; goats nave as little as 10 percent, the age and sex of the animal affects the quantity of fat deposited, older goats have more fat and females have more fat than males [1]. The nutrition of goats have been reported to reflect in their meat quality $[3,4,2]$. In regions where eating goat meat is very popular ,people mention the distinct flavor and palatability as major reasons for preferring goat meat (chevon) to mutton or beef, the value of a goat carcass depends on the quality of edible parts available for sale.

The inability of ruminant livestock farmers to feed their animals with high quality forages all year round remains the most wide spread technical constraint facing ruminant productivity in the developing nations [5]. Contemporary ruminant feeding in a developing country like Nigeria is partly geared towards searching for inexpensive readily available feed resources, can partly or wholly replace the scarce and expensive feed stuffs and inadequate forages [6]. 
Since grasses and legume which constitute a major proportion of forages, which are the basal feed for ruminants, are usually in short supply during the long dry season, there is need therefore to feed ruminants with leaves (browse) from trees, especially those that are evergreen and also do not bear fruist/seeds that are in direct use by man. Consequently this study was therefore designed to study the effect of four (4) browse species (Gmelina, Teak, Tamarind and Neem) on the chemical composition and quality attributes of meat from West African dwarf goats, Given the health challenges faced the world over today, the need to search for feed materials that can help in the dry season feeding of goats and at the same time produce high quality and health promoting meat can not be overemphasized.

\section{MATERIALS AND METHODS Experimental Location}

The feeding trial was carried out at the Small Ruminants Unit of the Livestock Teaching and Research Farm, Department of Animal Production, Kogi State University, Anyigba, which lies on Latitudes $7^{0} 15^{1}$, and $7^{0} 29^{\prime} \mathrm{N}$ of the equator and Longitudes $7^{0}$ $11^{1}$ and $7^{0} 32^{1}$ East of the Greenwich Meridean [7]. It is located in the derived Savannah zone of Nigeria. The annual rainfall ranges between $1400 \mathrm{~mm}-1500 \mathrm{~mm}$ with about 6-7 months of rainfall. The ambient temperature ranges from $25{ }^{\circ} \mathrm{C}$ to $35{ }^{\circ} \mathrm{C}$ with the highest in March and April [8].

\section{Experimental Feed Materials, Preparation, Animal Management and Experimental Procedure}

The experimental feed materials were bambara nut offal, Cereal spent grain (from millet), table salt, bonemeal and Gmelina (Gmelina arborea), Tamarind (Tamarindus indica), Neem (Azadirachta indica) and Teak (Tectona grandis) leaves. All the feed components were sourced from Anyigba and its environs. The browse leaves were harvested from Kogi State University, Campus, Anyigba.

Twenty (20) yearling West African dwarf bucks with weight range of $9.80 \mathrm{~kg}$ to $10.30 \mathrm{~kg}$ and aged about 12 months, were sourced from Anyigba and its environs. They were conditioned to stability by feeding them adequately for 1 week. The animals were treated with Ivomec at $0.25 \mathrm{~mL} /$ goat to control both endo and ecto parasites. The animals were ear-tagged for identification and were randomly divided into 4 treatments of 5 animals each. The experiment lasted for 63days, after an adjustment period of seven (7) days. Animals in treatments $T_{1}, T_{2}, T_{3}$, and $T_{4}$ were fed Gmelina, Tamarind, Neem and Teak leaves respectively at $300 \mathrm{~g} /$ goat/day on cut and carry basis, after wilting for 24 hours. All the animals were given water ad libitum. Daily feed intake was calculated from differences between absolute feed served and leftover. At the end of the feeding trial, three (3) animals were slaughtered from each treatment and $60 \mathrm{~g}$ of flesh was cut off from the thigh of each of the slaughtered goats, $20 \mathrm{~g}$ of flesh each were cut off and analyzed for their proximate values, carcass $\mathrm{pH}$ was taken on the left side of the Carcass at the same point on the longissimus thoracis of lumborum between $5^{\text {th }}$ and $6^{\text {th }}$ rib [9]. The initial $\mathrm{pH}(\mathrm{pHi})$ was taken 30 minutes post mortem and the ultimate $\mathrm{pH}(\mathrm{PHu})$ was taken 24 hours postmortem, these were taken using penetrating electrode of a portable $\mathrm{pH}$ meter, the probe was calibrated with 4 and 7 standard buffer solutions before and after every reading the electrode was thoroughly washed with distilled water and cleaned with cotton towels. The drip loss was determined using $40 \mathrm{~g}$ of the meat, the meat samples were placed in a container on the supporting mesh and sealed to prevent air from entering the container, after 24 hours the samples were removed from the containers, bloated dry and weighed again, drip loss was expressed as percentage of initial weight as outlined by Berri et al., [10].

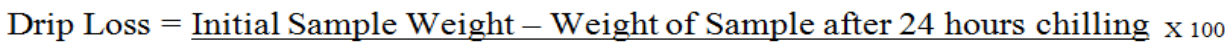

\section{Initial Weight}

The cooking loss was determined by putting $30 \mathrm{~mm} \times 30 \mathrm{~mm}$ of the meat from each goat carcass from each treatment in a plastic bag and cooking it to an internal temperature of 91C [11] the samples were left to cool to room temperature, the bags were opened and free juice drained [12], the cooked sample (B)was weighed and expressed as a \% of the sample before cooking (A) [13].

Cooking loss $(\%)=\frac{(A-B)}{A} \times 100$

Table-1: Composition of Concentrate Diet (Dry matter \%)

\begin{tabular}{|l|l|}
\hline Bambara nut offal & 46.00 \\
\hline Cereal Spent Grains & 46.00 \\
\hline Rice Offal & 4.00 \\
\hline Bone Meal & 3.00 \\
\hline Table Salt & 1.00 \\
\hline Total & 100 \\
\hline Calculated Nutrient Content Crude Protein & 18.80 \\
\hline Crude Fibre & 19.70 \\
\hline Metabolizable Energy & 2860.00 \\
\hline
\end{tabular}




\section{Proximate Analysis}

Samples of supplement diet, browse leaves and meat were prepared for analysis of their proximate composition. The protein content of the samples was determined by Kjeldahl method. Ether extract, crude fibre and ash content determination were according to standard procedure [14]. The nitrogen free extract (NFE) was calculated by subtracting the sum of the percentages of crude fibre, ether extracts, crude protein and ash from 100.
Experimental Design and Statistical Analysis

The experimental design was a completely randomized design (CRD). Data were analysed by a one way analysis of variance (ANOVA) and treatment means were compared and separated, where there were significant differences using least significant difference (LSD). With the aid of SPSS [15] Statistical package for social science version 23.0.

RESULTS AND DISCUSSION

Table-2: Proximate Composition of Browse Leaves and Concentrate Diet (\% DM)

\begin{tabular}{|l|l|l|l|l|l|}
\hline Nutrients & \multicolumn{5}{l|}{ Treatments } \\
\hline & T1 & T2 & T3 & T4 & Concentrate \\
\hline Crude protein & 10.05 & 12.35 & 9.50 & 9.85 & 18.25 \\
\hline Crude fibre & 11.30 & 11.80 & 13.10 & 14.85 & 18.20 \\
\hline Nitrogen free extracts & 34.15 & 33.00 & 31.80 & 34.00 & 52.00 \\
\hline Ether extracts & 2.50 & 3.00 & 2.75 & 2.90 & 2.50 \\
\hline Ash & 7.00 & 6.15 & 5.15 & 6.00 & 5.05 \\
\hline Dry matter & 65.60 & 66.20 & 62.30 & 67.35 & 96.00 \\
\hline Moisture & 34.40 & 33.80 & 37.70 & 32.60 & 4.00 \\
\hline
\end{tabular}

\section{Feed Intake Records of Experimental Goats}

The feed intake of the experimental goats is presented in Table-3, the daily concentrate intake range of $97.50-100 \mathrm{~g}$ which did not show significant $(\mathrm{P}<0.05)$ difference and daily feed intake range of 252.50 $386.00 \mathrm{~g}$ which were significantly $(\mathrm{P}>0.05)$ different were lower than 75.33-94.43g and at par with 253.00399.87g reported by Oyibo et al., [16] who fed browse plants to growing West African Dwarf Goats, the daily browse intake ranged from $152.50-288.00 \mathrm{~g}$, this range whose values were significantly $(\mathrm{P}<0.05)$ different were higher than $134.22-245.44 \mathrm{~g}$ reported by Ocheja et al., [17] for growing West African dwarf goat fed some browse species. These discrepancies could be due to differences in the formulation of the concentrates and the forages fed to the goats as well as the classes /ages of the goats used for the feeding trial.

Table-3: Feed Intake of Experimental Animals

\begin{tabular}{|l|l|l|l|l|l|}
\hline Parameter & \multicolumn{5}{l|}{ Treatment } \\
\hline & $\mathrm{T}_{1}$ & $\mathrm{~T}_{2}$ & $\mathrm{~T}_{3}$ & $\mathrm{~T}_{4}$ & SEM \\
\hline Daily Concentrate intake & 98.00 & 100 & 97.50 & 99.00 & 0.01 \\
\hline Daily Browse intake & $288.00 \mathrm{a}$ & $152.50^{\mathrm{d}}$ & $198.00^{\mathrm{c}}$ & $190.00^{\mathrm{b}}$ & 21.50 \\
\hline Total Daily feed intake & $386.00^{\mathrm{a}}$ & $252.50^{\mathrm{b}}$ & $295.50^{\mathrm{c}}$ & $289.00^{\mathrm{c}}$ & 22.00 \\
\hline
\end{tabular}

$\mathrm{a}, \mathrm{b}, \mathrm{c},=$ Means on the same row with different superscripts differ significantly $(\mathrm{P}<0.05)$. $\mathrm{SEM}=$ Standard Error of the Means

\section{Chemical Composition of Meat from West African Dwarf Goats fed Some Browse Plants}

The proximate composition of meat from West African dwarf goats fed some browse plants is presented in Table-4, the moisture and ash contents were not significantly $(\mathrm{P}<0.05)$ different. The fat values ranged from $4.45 \%(\mathrm{~T} 2)-10.05 \%(\mathrm{~T} 1)$, the fat content of T1 $(10.05 \%)$ was at par with $10 \%$ optimum fat content for goat meat reported by Steele [2] and appears to be the most suitable fat content to facilitate flavor, juicyness, tenderness and palatability. Carcass fat content and composition are influenced by age, sex, breed, body weight and dietary factors [18] the relatively low carcass fat content in goats affects the conversion of muscles to meat and hence, meat quality
[19]. Goat meat with less sub cuteanous fat are most prone to moisture losses and cold shortening subsequent to chilling, this may lower the meat quality and the dressing percentage, cold shortening in lean goat carcasses can be better managed or prevented by electrical stimulation of the carcass as well as post mortem aging or blade tenderization [11]. The protein content ranged from $18.40-23.15 \%$ and showed significant $(\mathrm{P}<0.05)$ differences, $\mathrm{T} 1$ (Gmelina) had the highest protein content the values were similar to 21.80 $-22.65 \%$ reported by Ocheja et al., [4]. For growing West African Dwarf goats fed cashew nut shell based diets as supplement to bamboo leaves. This similarity may be coincidental. 
Table-4: Chemical Composition of Meat from West African Dwarf Goats Fed Some Browse Species (\%)

\begin{tabular}{|l|l|l|l|l|l|}
\hline Parameters & \multicolumn{5}{l}{ Treatments } \\
\hline & $\mathrm{T}_{1}$ & $\mathrm{~T}_{2}$ & $\mathrm{~T}_{3}$ & $\mathrm{~T}_{4}$ & $\mathrm{SEM}$ \\
\hline Protein & $23.15^{\mathrm{a}}$ & $18.40^{\mathrm{b}}$ & $20.00^{\mathrm{b}}$ & $19.80^{\mathrm{b}}$ & 1.20 \\
\hline Fat & $10.05^{\mathrm{a}}$ & $4.45^{\mathrm{c}}$ & $7.50^{\mathrm{b}}$ & $7.65^{\mathrm{b}}$ & 1.02 \\
\hline Ash & 0.86 & 0.97 & 0.96 & 0.89 & 0.49 \\
\hline Moisture & 63.60 & 65.10 & 64.60 & 64.65 & 0.87 \\
\hline
\end{tabular}

$\mathrm{a}, \mathrm{b}, \mathrm{c}=$ Means on the same row with different superscripts differ significantly $(\mathrm{P}<0.05)$. SEM $=$ Standard Error of the Means.

\section{Chemical Composition and Some Quality Attributes of Meat from West African Dwarf Goats fed Some Browse Species}

The chemical composition and some Quality attributes of meat from West African Dwarf Goats feed some browse species is summarized in Table-5. Initial $\mathrm{pHi}$ and ultimate $\mathrm{pHu}$ were both not significantly $(\mathrm{P}>0.05)$ different, this was in line with the report of Budimir et al., [20] who reported no significant $(\mathrm{P}>0.05)$ differences 24 hours post slaughter in lambs slaughtered 40- - 60 days and attributed this to the strength of the myofibrils within 24 hours post slaughter.

The pHu range of $5.75-6.10$ were lower (less acidic) than the range of $5.2-5.8$ reported by Boughani and Araba [21]. Simela et al., [22] reported a pHu range of $5.8-6.2$, the high $\mathrm{pHu}$ values of goat meat suggests that goats are generally more prone to peri mortem stress. Goat carcasses with lower $\mathrm{pHu}$ tend to be more tender with lower shear force value and better calorimetric values [22] than those with a high $\mathrm{pHu}$ the susceptibility of goats to peri mortem stress is apparently associated with the excited nature of goats, $\mathrm{pHu}$ may affect several objective and sensory quality characterstics of meat ie colour, water holding capacity, thus it is accepted and used as the main indices of meat quality commercially.

Drip loss values $(5.20-8.10 \%)$ were significantly $(\mathrm{P}<0.05)$ different, the values were at par with $5.50-7.50 \%$ reported by Ocheja et al., [23] for West African dwarf goats fed cashew nut shell based diets, drip losses from goat meat have been reported to be as high as $8 \%$ [24], this tends to lower the dressing percentage. The cooking loss ranged from $18.00 \%-$ $23.75 \%$, the values were significantly $(\mathrm{P}<0.05)$ different, Cooking losses from goat meat tends to be high $(35 \%)$ and this detracts from the sensation of juiciness, cooking losses contributed at least in part to the perception of consumers that goat meat is less juicy than lamb or mutton [24] this result also agreed with that obtained by Choi et al., [12] who reported that differences in diets affects cooking losses of Korean goats fed different browses.

Table-5: Quality Attributes of Meat from West African Dwarf Goats feed some Browse Species

\begin{tabular}{|l|l|l|l|l|l|}
\hline S & \multicolumn{5}{|l|}{ Treatments } \\
\hline & $\mathrm{T}_{1}$ & $\mathrm{~T}_{2}$ & $\mathrm{~T}_{3}$ & $\mathrm{~T}_{4}$ & SEM \\
\hline Drip loss (\%) & $5.20^{\mathrm{b}}$ & $8.10^{\mathrm{b}}$ & $7.30^{\mathrm{b}}$ & $7.35^{\mathrm{b}}$ & 0.99 \\
\hline Cooking loss (\%) & $18.00^{\mathrm{b}}$ & $23.75^{\mathrm{a}}$ & $23.00^{\mathrm{a}}$ & $23.30^{\mathrm{a}}$ & 2.00 \\
\hline $\mathrm{pH}$ (initial) & 6.70 & 6.62 & 6.65 & 6.60 & 0.75 \\
\hline $\mathrm{pH}$ ( ultimate) & 5.75 & 6.05 & 610 & 5.85 & 0.63 \\
\hline
\end{tabular}

$\mathrm{a}, \mathrm{b}=$ Means on the same row with different superscripts differ significantly $(\mathrm{P}<0.05)$. $\mathrm{SEM}=$ Standard Error of the Means

\section{CONCLUSION AND RECOMMENDATIONS Conclusion}

Gmelina (T1) was most palatable to the goats and hence recorded the highest daily browse intake and hence total feed intake. Meat from Goats from T1 (Gmelina) had the best array of nutrients. T1 (Gmelina) produced goat meat with the best meat Quality

\section{Recommendations}

Gmelina leaves at 300g/goats/day supplemented with bambara nut and cereal spent grain based concentrate diet is recommended for feeding yearling West African dwarf goats especially during the long dry season for improved meat quality.
Further studies should also be carried out using other classes of ruminants such as sheep and cattle

\section{REFERENCES}

1. Webb EC. Goat Meat Production, Composition and Quality. Animal Frontiers, 2014; 4(4):33-37.

2. Steele M. Goats, the Tropical Agriculturalist Series. CTA/Macmillan. 1996; 110-114.

3. Oguche GH, Ocheja JO, Omonzokpia OF, Jibrin R. Whole sale cuts and organo-leptic properties of meat of west african dwarf goats fed diets containing graded levels of cashew nutshell. International Journal of Agricultural and Veterinary Sciences (IJAVS). 2018;4(4):47-52.

4. Ocheja JO, Ayoade JA, Attah S, Netala J, Ocheni J, Oyibo A. Carcass characteristics of growing 
West African dwarf goats fed diets containing graded level of steam- treated cashew Nut Shell. Animal and Veterinary Science, 2016; 4(3-1):1822.

5. Bawala TO, Akinsoyinu AO. Nutritional evaluation of browsers Gliridia sepium and Fcus thoningii foliage in goat dut. Energy utilization and requirement. Proceeding of $37^{\text {th }}$ conference of University of Agriculture, Abeokuta, Nigeria, 2002; 174-176.

6. Okoruwa MI, Adewumi MK. Effect of replacing Panicum maximum with dried pineapple pulp on nutrient digestibility and nitrogen balance of West African dwarf sheep. Nigerian Journal of Animal Science. 2010;32:108-15.

7. Ifatimehin OO, Musa SD, Adeyemi JO. An analysis of the changing land use and its impact on the environment of Anyigba Town, Nigeria. Journal of sustainable development in Africa. 2009 Mar;10(4):357-64.

8. Kowal JM, Knabe DT, Hydrological Technical Committee. An agroclimatological atlas of the northern states of Nigeria, with explanatory notes. 1972.

9. Shija DS, Mtenga LA, Kimambo AE, Laswai GH, Mushi DE, Mgheni DM, Mwilawa AJ, Shirima EJ, Safari JG. Chemical composition and meat quality attributes of indigenous sheep and goats from traditional production system in Tanzania. Asian-Australasian journal of animal sciences. 2013 Feb;26(2):295-302.

10. Berri C, Besnard J, Relandeau C. Increasing dietary lysine increases final $\mathrm{pH}$ and decreases drip loss of broiler breast meat. Poultry Science. 2008 Mar 1;87(3):480-4.

11. Kannan G, Gadiyaram KM, Galipalli S, Carmichael A, Kouakou B, Pringle TD, McMillin $\mathrm{KW}$, Gelaye S. Meat quality in goats as influenced by dietary protein and energy levels, and postmortem aging. Small Ruminant Research. 2006 Jan 1;61(1):45-52.

12. Choi JH, Choi YS, Kim HW, Song DW, Kim CJ. Effects of Post mortem Temperature on the Physico-Chemical Characteristics of Pekin Duck Breast Muscle. Poultry Science, 2016; 95:645650.

13. Yang Z. PAML 4: phylogenetic analysis by maximum likelihood. Molecular biology and evolution. 2007 Aug 1;24(8):1586-91.
14. AOAC, Association of Official Analytical Chemists. Official methods of Analysis $17^{\text {th }}$ edition Washington, D.C. 2000; 1-20.

15. SPSS, Statistical package for Social Science. Version 23.0 SPSS Inc, 2015; 5-17.

16. Amina O, Jude E, Ibrahim S, Yaro UA, Hassanatu AS, Theophilus EA, Tsobaza AA. Serum Biochemistry of West African Dwarf Goats Fed, Some Browse Species Supplemented with a Concentrate Diet. Animal and Veterinary Sciences. 2020 Apr 14;8(2):41-44.

17. Ocheja JO, Oguche GH, Omata SB, Ode CO, Oyibo A. Performance and haematological profile of growing west african dwarf goats fed concentrate diet supplemented with browse plants. Journal of Agricultural Production and Technology ISSN. 2017;2360:9364.

18. Casey NH, Van Niekerk WA, Webb EC. Goat Meat, In: Caballera B, Trugo L, Finglass P, (Editors), Encyclopedia of Food Sci and Nutrition Academic Press, London, 2003; 2937-2944.

19. Webb EC, Casey NH, Simela L. Goat Meat. Small Ruminant Research, 2005; 60:153-166.

20. Budimir K, Trombetta MF, Francioni M, Toderi M, D'Ottavio P. Slaughter performance and carcass and meat quality of Bergamasca light lambs according to slaughter age. Small Ruminant Research. 2018 Jul 1;164:1-7.

21. Boughalmi A, Araba A. Effect of feeding management from grass to concentrate feed on growth, carcass characteristics, meat quality and fatty acid profile of Timahdite lamb breed. Small Ruminant Research. 2016 Nov 1;144:158-63.

22. Simela L, Webb EC, Frylinck L. Effect of sex, age, and pre-slaughter conditioning on $\mathrm{pH}$, temperature, tenderness and colour of indigenous South African goats. South African journal of animal science. 2004 Jan 2;34(5):208-211.

23. Ocheja JO, Abalaka EO, Akinleye SB, Usman GO, Netala J, Oyibo A, Lamido M, Dauda AN. Quality Attributes of Meat of West African Dwarf Goats. Fed Cashew Nut shell Based Diets. Nigerian Journal of Animal Science and Technology (NJAST). 2020 Oct 24;3(3):64-71.

24. Tshabalala PA, Strydom PE, Webb EC, De Kock HL. Meat quality of designated South African indigenous goat and sheep breeds. Meat Science. 2003 Sep 1;65(1):563-70. 